\title{
The Muslim Millennial family typology: the role of Muslim family circumflex model to avoid parents' violent behavior against children in Indonesia
}

\author{
Supaat
}

IAIN Kudus Indonesia

E-mail: supaatkudus@yahoo.com

Salmah Fa'atin

IAIN Kudus Indonesia

E-mail: salmasyaldiena@gmail.com

DOI: 10.18326/ijims.v9i1. 57-81

\begin{abstract}
The shifting phenomena of a Muslim family function in the millennial era, in sociological perspective, require an effort of adjustment in the patterns of family behavior interactions. The role of family leader as the main breadwinner is not the only principle because a stay at home dad is one of alternatives for Indonesian couples to foster their family. Circumflex model on marital and family pattern system, according to Olson, is specifically designed for planning treatment and effective results on marital and family therapy. A healthy Muslim family will function properly including diminishing parents' violent behavior against their children. This study explores the Muslim family typology in the millennial era based on Circumflex model in the dimensions of cohesion,
\end{abstract}


adaptability, and communication, and respectively it encloses the roles of each type in reducing parents' violent behavior against their children. This article occupies qualitative method and education psychological approach. Based on the interview and observation as the primary tools for data collection, this research reveals two findings. Firstly, the common Muslim family typology in millennial era based on Circumflex model includes the types of extreme, midrange, and balanced. In fact, the balanced type of Muslim family promotes appropriate functions in the dimensions of cohesion and adaptability. Secondly, the balanced type of Muslim family is capable to bring harmony to the family, and assist the individual to override the difficult time during the family life. Thus, it will eliminate the parents' violence behavior to their children.

Fenomena pergeseran fungsi keluarga muslim di era millenial, dalam prespektif sosiologi, menuntut upaya penyesuaian dalam pola interaksi perilaku keluarga. Peran kepala keluarga sebagai pencari nafkah tunggal tidak menjadi satusatunya acuan, karena pria menjadi bapak rumah tangga (stay at home dad) merupakan salah satu alternatif bagi beberapa pasangan dalam membangun suatu keluarga di Indonesia. Model sirkumpleks dari sistem pola keluarga dan perkawinan, menurut Olson, secara khusus dirancang untuk perencanaan treatment dan hasil yang efektif pada marital dan familiy therapy. Keluarga muslim yang "sehat" akan dapat berfungsi secara memadai, termasuk dalam upaya meredam perlaku kekerasan orangtua pada anak. Penelitian ini menelusuri tipe pola keluarga muslim di era millenial berdasarkan model sirkumpleks, yakni dimensi kedekatan keluarga (cohesion), dimensi adaptabilitas keluarga (adabtability) dan dimensi komunikasi (communication), kemudian mengungkap peranan masing-masing tipe dalam upaya meredam perilaku kekerasan orangtua pada anak. Artikel ini menggunakan metode kualitatif dan pendekatan Psikologi Pendidikan. Berdasarkan interview dan observasi sebagai alat utama pengumpulan data, penelitian ini menghasilkan beberapa temuan. Pertama, tipe umum pola keluarga muslim di era millenial berdasar model sirkumpleks adalah tipe ekstrem (extreme), tipe rentang tengah (mid range) dan tipe seimbang (balanced). Keluarga yang berfungsi memadai adalah keluarga yang bertipe seimbang dimensi kedekatan dan adabtabilitasnya. Kedua tipe tersebut yang mampu mewujudkan keharmonisan keluarga, dan sangat membantu individu 
The Muslim Millennial family typology: the role of Muslim family circumflex... (Supaat, Salmah Fa'atin)

dalam melewati masa-masa sulit ketika menemui problem kehidupan, sehingga meniscayakan perilaku kekerasan orangtua pada anak akan tereleminir.

Keywords: Family interaction; Circumflex model; Child abuse; Educational psychology

\section{Introduction}

A family is an important social institution in Islam to structure the best generation. Children characters are determined by parents' strategic roles. The family takes an important part in the children educational process. Children behavior is influenced by the interaction within families. Zakiah Drajat research reveals that $83 \%$ of human behaviors are influenced by what they see, $11 \%$ ofwhat they hear, and the $6 \%$ of what the other mixed stimulus. The family advice only has $11 \%$ effectiveness. The best method to influence the children is giving the children a good model. Both wife and husband have responsibility for the successes of their children education. The Islamic concept in parenting says that parents are the best model who will be followed by their children.

The function of a family has been shifting. In the concept of gender equality, women do not want to leave behind men. A woman does not only take care of domestic activities but also have equal positions as a man. A father as a patriarch handles domestic activities while his wife is at work. This phenomenon is called as stay at home dad or stay-at-home dad, ${ }^{1}$ or stay-at-home fathers ${ }^{2}$, stay-at-home fathers ${ }^{3}$ become an alternative

${ }^{1}$ Andrea Doucet dan Laura Merla, "Stay-at-Home Fathering," Community, Work Eु Family 10, no. 4 (November 2007): 455-73, https://doi.org/10.1080/13668800701575101.

2 "Beth A.Latshaw and Stephanie I. Hale 'The domestic handoff': stay-at-home fathers' time-use in female breadwinner families: Journal of Family Studies: Vol 22, No 2," n.d.

${ }^{3}$ Emily Stevens, "Understanding Discursive Barriers to Involved Fatherhood: the Case of Australian Stay-at-Home Fathers," Journal of Family Studies 21, no. 1 (Januari 2015): 22-37, https://doi.org/10.1080/13229400.2015.1020989. 
for Indonesian Muslim family ${ }^{4}$. Being jobless and under an agreement in taking care of the family are the reasons that make husband become a stay at home dad. Commonly, a family decides who will take care of the domestic activities based on the husband personality.

Special studies on the millennial Muslim family typology in Indonesia have not been conducted yet, but there are some researches related to family roles on children education. Arifin reviews about revitalizing family as the environmental education ${ }^{5}$. The concept of family education according to Fauzil'Adzim, ${ }^{6}$ about family Education: Building Children's Character And Mental Health In an Era of Millennial Doctrines 7 . Build A Muslim Family In A Global Era: The Struggle Between Tradition And Modernity. ${ }^{8}$ Some researches on millennial Muslims also have been conducted in several countries such as Millennial Reverie: Muslims in Britain'. Muslim, period. American, period”: millennial Muslim identities in the contemporary United States. ${ }^{10}$ It is digitally defined: how millennial Muslim represent themselves online. ${ }^{11}$

${ }^{4}$ Cindy \& Maria Dwi Yanika Hesti Nugraha Widhiastuti, "Peranan Stay at Home Dad dalam Membentuk Keluarga Sehat dan Harmonis," PSIBERNETIKA 6, no. 2 (2013): 59-73.

${ }^{5}$ Siful Arifin, "Revitalisasi Keluarga Sebagai Lingkungan Pendidikan," Kariman: Jurnal Pendidikan dan Keislaman 5, no. 1 (2017): 1-22.

${ }^{6}$ Rohmatul Faidah, "Konsep Pendidikan Keluarga: Studi Analisis Atas Pandangan Muhammad Fauzil Adhim” (UIN Sunan Ampel Surabaya, 2013).

${ }^{7}$ Miftahul Hakiki, "Pendidikan Keluarga: Membangun Kesehatan Mental Dan Karakter Anak Di Era Millenial,” An-Nisa' 10, no. 1 (2017): 115-28, http://ejournal.iain-jember. ac.id/index.php/annisa/article/view/645/526.

${ }^{8}$ Toto Suharto, "Membina Keluarga Muslim Di Era Global: Pergumulan Antara Tradisi Dan Modernitas," Musãwa Jurnal Studi Gender dan Islam 10, no. 2 (2011): 205-214.

9 Ida Glaser, "Millennial Reverie: Muslims in Britain'," International Review of Missions 27, no. 107 (1938): 341-54.

${ }^{10}$ Ledaman Bliss Zakarison, “'Muslim, period. American, period': millennial Muslim identities in the contemporary United States,” 2016.

${ }^{11}$ Abdul Mustaqim, Tafsir Feminis versusTafsir Patriarkhi (Yogyakarta: Sabda Persada, 2003), 119-20. 


\section{Millennial muslim family phenomenon and dogma in Indonesia}

\section{The family concept in Islam:perspective and its function}

Islam gives great attention in family education because the family is the Foundation for the welfare of the nation. The Quran and hadith ${ }^{12}$ give clear instructions about family education. ${ }^{13}$ As a small part of the community, a family also has a leader and members. The family becomes a madrasah (education institution) to study loyalty, honesty, compassion and so forth.

The Quran concepts about shaping the family are well known as sakinah, mawaddah, andrahmah. The meaning of sakinah is peaceful and serenity. This is an important principal to build blissful family. The meaning of mawaddah is the way of ignoring self-enjoyment and selfinterest for the other people. Mawaddah indicates someone feelings to the partner because of their superiority. Mawaddah describes the sense of affection against the partner because of their potentials. It can be in the form of great physical, professional position, respectful people, and the other positive attitude. While, rahmat is the sense of love and compassion towards the partner regardless of the weakness and less power, either in material or immaterial. ${ }^{14}$

Sakinah, mawaddah, and rahmat do not automatically manifest in the family. It should be endeavored by preparing the heart. Sakinah is from the heart then it manifests in the form of behaviors..$^{15}$ The serenity can be established if family exponents play their roles properly, adhere to the values of Islam and build a synergistic interaction in social community ${ }^{16}$

\footnotetext{
${ }^{12}$ Among them are inside Surah ar-Rum: 21, al-Nisa':59, surah 16: 72

${ }_{13}$ MQ Shihab, "Membumikan Al-Quran," Bandung: Mizan, 1992, 253, http://www. academia.edu/download/35715012/membumikan-al-quran.pdf.

${ }^{14}$ Quraish Shihab, Perempuan, Jakarta: Lentera Hati, 2006, 141.

${ }^{15}$ Shihab, 141.

${ }^{16}$ Dadang Hawari, Al-Qur'an ilmu Kedokteran jiwa dan Kesehatan Jiwa, Yogyakarta: PT Dana Bhakti Yasa, 1995, 236.
} 
The fundamental purposes of Surah al-Nisa verse 34 are related to women's equality issues between men and women. It can be viewed from the two-dimensional aspects. The first aspect is the equality in the excogitation or the concept of nafs wahidah, and the second is the equality in the religious issues. Qawwamah in the al-Nisa' verse 34 does not have to be interpreted as men leadership, but it is more precise as women guardian. Al-Qur'an sees that women are equal to men. Women are not men subordinate. ${ }^{17}$ Qur'an asserts that men and women are equal in the sight of Allah. Both of them become protective each other. In Quran context, there is no ontological hierarchy that place women as man subordinate. ${ }^{18}$ Both husband and wife have same duties and responsibilities. The duties of the couple are creating comfort, tranquility, and protect each other. ${ }^{19}$ In the Islamic perspective, the biological differences are not the factors to determine the quality of human status. Women are seen not only from their reproduction ability but also from their social functions or their roles in public sectors. It will support the attainment of egalitarianism. There is no indication about states of the primordial existence based on their spiritual potential. ${ }^{20}$ Positive values will remain in the household if there is equality in the wife-husband relationship. Both wife and husband must get their right and obligation proportionally. ${ }^{21}$

Based on al-Safsafi Ahmad al-Mursi ${ }^{22}$ family is the smallest social unit of society as a product of the bond of kinship between individuals with

17 Fauzeya Zahera Rahman, "Digitally defined: how Muslim millennials represent themselves online" 2015.

${ }^{18}$ Mustaqim, Tafsir Feminis versus Tafsir Patriarkhi, 119-20.

${ }^{19}$ Muhammad Nur Kholis, "Konsep Kepala Keluarga Antara Laki-Laki Dan Perempuan Dalam Surat an Nisa (4) Ayat 34,” ISTINBATH: Jurnal Hukum 12, no. 2 (2015): 274-290.

${ }^{20}$ Amina Wadud, Inside The Gender Jihad (Oxford: Oneword, 2006), 93.

${ }^{21}$ Siti Musdah Mulia, Membangun Surga di Bumi: Kiat-kiat Membina Keluarga Ideal dalam Islam, Jakarta: Elex Media Komputindo, 2011.

${ }^{22}$ Al-Safsâfî Ahmad Al-Mursi, Al-Qiyam al-Usriyyah bain al-Asâlah wa al-Mu'âsarah (Kairo: Dâr al-Âfâq al-Arabiyyah, 2002), 19. 
each other. There are two categories of families; small family (usrah) and big family ('ailah). Family has seven functions that the religious function refers to a religious commandment to build family. Meanwhile, the biological function relates to parents that give their children opportunity to grow and develop properly. The economic function accommodates each family member to set their fulfillment of needs with the availability of family resources. The educational function posits family as the first institution which provides religious education and culture. It obtained at the first time through direct imitations in family environment. The social function describes family as a place to obtain social-religious values. The communication function explains about the important role of family in delivering the everyday life experienced for their members. The redemption function closely relates to families' mandatory to maintain next generation quality. They must not leave a weak generation in the religious, physical, mental, and economic sectors. ${ }^{23}$

There is a religious concept (al-mafhûm al-dîn $\hat{\imath}$ ) in a Muslim family. The family members are bound to religious ties to reach noble personality (al-syakhsiyyât al-sawiyyah). This concept emphasizes that a Muslim family should be able to structure the members in order to have noble personality indicated by the nature of love and affection, compassion, respect for others, honesty, patience, compliance (qana'ah) and forgiving. ${ }^{24}$

The importance of family functions is as the center of education and the Islamic guidelines on favorable atmosphere. First, the goal is to encourage tranquility, harmony based on mutual love and affection as mentioned in Qur'an, Surah Al-Rum: 21. Second, choosing an ideal partner is by emphasizing on the requirements of morals and religion,

${ }^{23}$ Al-Qur'an Surat al-Nisa ayat 9 dan surat al-Tahrim ayat 6

${ }^{24}$ Toto Suharto, "Membina Keluarga Muslim Di Era Global: Pergumulan Antara Tradisi Dan Modernitas." 
as the words of Prophet Muhammad. Third, each member of a family realizes and fulfills the rights and responsibilities. Husband and wife should reciprocally understand, respect and appreciate each other, and then claim responsibility according to the functions and positions in the household. ${ }^{25}$ There are no structural relationships such as the superiors and subordinates. A relationship results a function such as appropriate relationship roles and functions. ${ }^{26}$ The Prophet's hadith narrated by Bukhari and Muslim indicates family functions and responsibilities. Each person is a leader and will be subject to liability for his/her leadership.

Children moral education requires cooperation and involvement of many parties. The involvement includes families, communities, and schools. The moral internalization should be gradually implemented on a process. A family is supposed to optimize the role in the interaction between parents and children, as well as in taking time and greater attention to children more than what they have got from schools ${ }^{27}$

\section{The function shifting of the Indonesian Muslim family}

The change can be seen in the way of life and relationships in the families. This is due to the lack of family time between children and their parents to engage. It causes less intensive communication and interaction among family members. Family relationships that are originally strong become extremely different. Careers and jobs have disrupted interpersonal relationships in the family. The family's social and emotional role tends

${ }^{25}$ Muhammad Rusydi, "Relasi Laki-laki dan Perempuan dalam al-Qur'an Menurut Amina Wadud,” MIQOT: Jurnal Ilmu-ilmu Keislaman 38, no. 2 (2014).

${ }^{26}$ Fatimah Zuhrah, "Relasi Suami Dan Istri Dalam Keluarga Muslim Menurut Konsep Al-Quran: Analisis Tafsir Maudhuiy,” Journal Analytica Islamica 2, no. 1 (2013): 177-192.

${ }^{27}$ Imam Sutomo, "Modification of character education into akhlaq education for the global community life," Indonesian Journal of Islam and Muslim Societies 4, no. 2 (2014): 291316. 
to change into the economic role. ${ }^{28}$

Hectic parents can reduce their child socialization process. The existence of child care institutions, playgroups, kindergartens, and schools accommodates most of children's time for families. It makes shifting in family functions and replaced by schools and their social environment. In the millennial era, media technology has replaced the role of families in intervening in children's personal development. The lack of serious implementation of the family's normative role makes rampant acts of violence in the family. The main victims are children and wives. ${ }^{29}$

Since the 18th century, the rapid development of industrializations has changed human civilization. It influenced the function shifting of Muslim families in Indonesia. It changes the role of women in Muslim families. Women do not only do their domestic activities but also involve in the public sector as career or professional women. There is a shifting function of the husband domestication phenomenon and the wives role as a breadwinner in the family. ${ }^{30}$

There are eight roles related to the position of husband and wife in the family literature. Husbands and wives play roles as housewives, caregivers, socialization for children, sexuality, recreational roles, health roles, and family roles. The role of housewife, child care and sexual roles is given to the wife normatively. The role of breadwinner is imposed on the husband. The roles of kinship and child socialization are imposed on husband and wife ${ }^{31}$

There is a value shifting that occurs onto husband and wife after marriage because of the issue of gender equality. Currently, women have

${ }^{28}$ Evi Munita Sandarwati, "Revitalisasi Peran Orang Tua dalam Mengurangi Tindak kekerasan Terhadap Anak"IPI Search Articles,” n.d., 293.

${ }^{29}$ Evi Munita Sandarwati, "Revitalisasi Peran Orang Tua dalam Mengurangi Tindak kekerasan Terhadap Anak"IPI Search Articles."

${ }^{30}$ Muassomah Muassomah, "Domestikasi Peran Suami Dalam Keluarga," EGALITA, 2012.

${ }^{31}$ F. Ivan Nye, Role Structure and Analysis of the Family, London: Sage Publications, 1976, $12-13$. 
begun to plunge into the public sphere in various agencies as career women. It makes men change their conservative perspective. A husband currently has a role in domestic realm. The phenomenon of stay-at-home dad has began to be introduced by the world as a new paradigm towards the decision to determine gender roles in marriage. ${ }^{32}$ The phenomenon of stay-at-home-dad in Indonesia is actually not new, especially in small towns and rural areas. ${ }^{33}$

Stay-at-home dads decide to take over the role of housewives as caregivers and are responsible for domestic matters at home, while the wives work outside of home to earn life. However, some stay-at-home dads still have jobs at home. Stay-at-home dads can be freelancers, writers, painters, and musicians and so forth. This role exchange is still considered taboo in the view of Indonesian, so the stay-at-home dads must encounter the public stigma to maintain household harmony. ${ }^{34}$ The dominant of patriarchal culture in Indonesia vanquishes the existence of stay-at-home-dads in Indonesia. However, the most important thing before carrying out the role of husband as a stay-at-home dad is better to do some preparation and careful consideration to avoid the worst possibility and failure in fostering a healthy, harmony, sakinah, mawaddah, and rahmat as the purpose of marriage in Islam.

32 This can be evidenced by the many studies of the phenomenon of stay at home dad in various countries, although with a variety of different terms.Jessica Fischer dan Veanne N. Anderson, "Gender role attitudes and characteristics of stay-at-home and employed fathers.,” Psychology of Men EF Masculinity 13, no. 1 (2012): 16.

${ }^{33}$ Widhiastuti, "Peranan Stay at Home Dad dalam Membentuk Keluarga Sehat dan Harmonis."

${ }^{34}$ Nazhra Aulia Pramanada dan Adi Dinardinata, "Pengalaman Suami Menjadi Stayat-Home Dad Pada Usia Dewasa Awal (sebuah Studi Kualitatif Fenomenologis Dengan Interpretative Phenomenological Analysis)" (Undip, 2018). 


\section{The family type with circumflex model}

Circumflex model is a family and marriage system developed by Olson. ${ }^{35}$ This model is specifically designed for clinical assessment, clinical treatment planning and effective results in marital and family therapy. This model is developed to bridge the wide range of research, theoryy and practice. Variety of interaction patterns of behavior in the family focus on the independence in the relationship of the variable dimension of immediacy, flexibility, and communication. The value and importance of the third dimension in family life are, i.e. the dimension of family closeness (Cohesion), the adaptability family dimensions (Adaptability) and the dimensions of communication (Communication). ${ }^{36}$

The dimensions of the closeness of the family showed degrees of separateness or connectedness of individuals to their families. It shows the extent to which family members are separated or connected emotionally with the family. There are some specific variables which can be used as the standard for diagnosing and quantifying the closeness of the family. The first aspect for assessing the closeness of the family is the emotional attachment which felt by the family members. The family involvement is illustrated by the number of interactions that occur, and how their tendency to respond with compassion is the second aspect for assessing the closeness of the family. The third aspect is the parent-child relationship which includes closeness and boundaries in families. Fourth, the internal limits (time), space and decision-making, or external boundaries include friends and interesting recreation. ${ }^{37}$ The level of closeness with family system is measured through variables which are classified into four levels.

35 Olson, Russel, dan Sprenkel, Circumplex Model: Systemic Assesment and Treatment of Families (New York: Haworth Press Inc, 1988).

36 Seto Mulyadi dkk, 2017, Psikologi Pendidikan: Dengan Pendekatan Teori-teori Baru dalam Psikologi, Jakarta: Rajawali Press, 187.

${ }^{37}$ F Wals, Normal Family Process, New York: The Guildford Press, 2003. 
They are extreme low level (disengaged), medium-low level (separated), medium-high level of (connected) and extreme-high level (enmeshed). ${ }^{38}$

At the extreme level (disengaged), family members do not have attachments and commitments to one another. They prefer other people in fostering close relationships. Satisfaction in dealing with others is better than family. Balanced and connected levels are described as a condition where family members are able to establish good relationships and satisfying relationships with other family members as well as with other people. Extreme levels (enmeshed) are described as a force that attracts family members to always be in the family. Family relationships are too close to give rise to the excessive identification of the family, which impedes individual independence.

The dimensions of adaptability describe the dynamic family system to change. This is the family system to change the power structure, rules in establishing relationships, and rules in response to stressful situations and developments ${ }^{39}$. Complex model outlines the specific aspects that can be used to measure the dimensions of the family adaptability. The leadership aspects refer to the control in the family negotiations. It attempts to explain the way how they negotiate within the family deals to determine and implement applicable rules. The adaptability dimensions are classified into four levels, namely stiff, structured, flexible, and chaotic.

Structured and flexible levels are hypothesized as a state of good family function. At the extremely low level (rigid), there is a refusal from family members to adjust to changing needs and circumstances. Family leadership and control are very rigid. Authority figures are the decision makers. Structured families tend to have democratic leadership

38 Olson, Russel, dan Sprenkel, Circumflex Model: Systemic Assesment and Treatment of Families.

${ }^{39}$ Wals, Normal Family Process. 
patterns, as well as negotiations that also involve children. There is a clear division of roles and sharing between family members, rules (rules) are applied wisely. Families in the second middle level (flexible), families apply equal leadership, decision making is implemented democratically. Negotiations are applied openly and the active role of parents to invite children to participate. Regulations are adjusted to the development of each family member. Families at the extreme level (chaotic) implement leadership not so clearly, the member roles in the family are very chaotic, the application of discipline is inconsistent, is permissive and rules easily change. ${ }^{40}$

The dimension of family communication is a means of movement from the two previous dimensions. Communication, broadly, is defined as "sharing experiences". Communication is a factor that plays a role in the negotiation process in families who are undergoing changes due to their members' development. ${ }^{41}$ The family communication contains listening skills, speaking skills, self-disclosure, clarity, continuity tracking, and respect. In communication, there are positive dimensions and negative dimensions. ${ }^{42}$ Positive dimension describes the openness of family members in communicating (open family communication), which focused on freedom and the smooth exchange of information, either factual or emotional, the lack of barriers in communicating, as well as the existence of understanding and satisfaction in interaction. The negative dimension describes the reluctance to share among family members as well as selective and careful attitude to recognize the things that will be shared with fellow family members.

The circumflex model consists of closeness and adaptability.

\footnotetext{
${ }^{40}$ Wals, Normal Family Process.

${ }^{41}$ Wals, Normal Family Process.

42 Seto Mulyadi, Heru Basuki, dan Wahyu Rahardjo, Psikologi Pendidikan: Dengan Pendekatan Teori-teori Baru dalam Psikologi, Jakarta: Rajawali Press, 2017, 191.
} 
Communication stands independently and is an important means to lead a change in both dimensions. The combination of each of the four levels of proximity dimension and adaptability dimension can be arranged in a family type of circular model. It consists of 16 special types. There are three types of these typological types. ${ }^{43}$ First is extreme type, families whose dimensions of proximity and adaptability dimensions belong to the extreme level, namely rigidly-disengaged, chaotically-disengaged, rigidlyenmeshed, and chaotically-enmeshed. The mid-range type is a family with one of its dimensions being balanced, and the other dimensions are classified as extreme namely rigidly-separated, chaotical-separated, rigidlyconnected, chaotic technical-connected, structurally-disengaged, flexiblydisengaged, structurally-enmeshed, and flexibly-enmeshed. Balanced type is a family with both dimensions (proximity and adaptability) classified as balanced type, namely structurally-separated, structurally-connected, flexibly-connected, and flexibly-separated types.

According to Olson, a healthy family, a family that can have function adequately balanced family is the dimension of immediacy and dimension of adaptability. If closeness and attachment to deal with the family is too large, too many changes made and too stiff to turn, then the family could not perform its function properly. To create a healthy family communication is required, like open in communicating and in the problems often encountered in the family. A balanced family is a family of proximity dimension of each member of her family has the attachment (connected) against families and independence (independent) from his family. Families with balanced adaptability, able to maintain stability despite the still open up to those changes. A balanced family can also experience stress due to the existing requirements, along with the

${ }^{43}$ Olson, Russel, dan Sprenkel, Circumflex Model: Systemic Assesment and Treatment of Families. 
development and growth of every member of the family, but the family that can cope with stress more balanced that appears instead of the family in the extreme positions. ${ }^{44}$

\section{The typology of the millennial Muslim family in Indonesia}

Observations and interviews were conducted on the Muslim families in Central Java region upon 60 Muslim families with various employment, education, economic, and social status. The subjects of the research were family partners in the age range 19-38 years with a child. The general typology of the family Circumflex model based on Olson's ${ }^{45}$ theory involves extreme (extreme): rigidly-disengaged (RD), chaotically-disengaged (CD), rigidly-enmeshed (RE), and chaotic-enmeshed (CE) type, midrange type (mid-range): rigidly-separated (RS), chaotically-separated (CS), rigidly-connected (RC), chaotical-connected (CC), structurallydisengaged (SD), flexibly-disengaged (FD), structurally-enmeshed (SE ), and flexibly-enmeshed (FE), and balanced types: structurally-separated (SS), structurally-connected (SC), flexibly-connected (FC), and flexiblyseparated (FS) types.

There were two major typologies of Muslim family, mid-range and balanced types. While the extreme (extreme) type is only connecteddisengaged 3\%. The most common Muslim family typology was balanced type 65\% including S-S type 15\%, type S-C 15\%, type F-C 30\% and type F-S 5\%. Mid-range Muslim families cover 32\% consisting of type R-13\%, type C-S 10\%, type R-C 3\%, type C-C 3\%, type F-E 3\%.

${ }^{44}$ Olson, Russel, dan Sprenkel, Circumflex Model: Systemic Assesment and Treatment of Families.

45 Olson, Russel, dan Sprenkel, Circumflex Model: Systemic Assesment and Treatment of Families. 


\section{The typology of Circumflex model of the millennial Muslim families in Indonesia}

Family type differences were seen from how each of family members communicates physically and psychologically to get the best quality interaction. Balance in terms of closeness between family members will make a family more adaptive in confronting challenges. The functionality of a family was not seen from their education status and the economy level. Low levels of education and economy can build balance in their families.

The higher social status of Muslim families is not a guarantee for a family to have the balanced type. There are a number of Muslim families with higher social status precisely in the mid-range type. This is not the ideal type while compared to other Muslim families with lower social status backgrounds. Good functionality and interaction with their family members are not determined by high level of education, high level of social status and the amount of family income. Functionality, harmonious relationships and positive communication among family members are important pillars to ignite the balanced family type. A balanced family type got from the dimensions of closeness which consists of aspects of emotional bonding, interaction, and response with affection and good relations between parents and children, when it combined with adaptability dimensions which consist of aspects of leadership flexibility and role sharing within the family as well as rules applied flexible and structured. ${ }^{46}$ Adaptability is the ability to modify and respond to changes in a family. The dimensions of adaptability that take place at the point of balance are found in family life with the role of the wife as a career

\footnotetext{
${ }^{46}$ Anita Rahmawati, "Harmoni dalam Keluarga Perempuan Karir: Upaya Mewujudkan Kesetaraan dan Keadilan Gender dalam Keluarga," PALASTREN Jurnal Studi Gender 8, no. 1 (2016): 1-34.
} 
woman in the public sphere and the role of the husband as stay-at-homedad. This balance is achieved because the relationship of husband and wife who are able to adjust to each other. The change in structure is the exchange of roles between husband and wife. The wife acts as a breadwinner, and the husband is willing to carry out domestic duties. ${ }^{47}$

The family structure with a conventional perspective in Indonesia who determines the typical role of family members has been modified by a married couple. Modification of the partner's specific role is carried out without losing the typical role of the partner. The wife continues to take part and play a role in carrying out domestic duties, while the husband continues to work and earn income to provide for the family even though the amount of it is not greater than the wife's income. This reflects the roles that exist in this Muslim family to take place dynamically rather than roles in traditional family type pairs that tend to prioritize stability based on the function of conventional structures. ${ }^{48}$ Cohesiveness in families with greater income tends to be at a balanced point. Independent couples are more autonomous. Emotional ties and togetherness in the family are at a proportional level. The time they have together with the environment outside the family, such as parents and friends in the work environment, makes this husband and wife togetherness shares the intimacy they have. The financial independence of the wife and her role in supporting the family; and the husband's willingness to be willing to carry out domestic tasks also contributes to a balanced cohesiveness because their roles are more flexible. ${ }^{49}$ Family independence will be obtained as a balanced family base. This will be able to foster an open attitude towards various social changes.

\footnotetext{
${ }^{47}$ Sri Fadilah, "Kesetaraan Gender : Fenomena Pergeseran Peran Ekonomi Wanita Dari Tulang Rusuk Menjadi Tulang Punggung," Mitra Gender (Jurnal Gender dan Anak) 1, no. 1 (2018): 18-26.

${ }^{48}$ Nurul Utami, "Pengalaman Komunikasi Keluarga Istri yang Berpendapatan Lebih Besar dari Suami,” Jurnal Kajian Komunikasi 4, no. 1 (2016): 101.

${ }^{49}$ Nurul Utami, Pengalaman Komunikasi..., 100.
} 


\section{The Muslim family typology and its roles to avoid parents' violence against children in Indonesia}

Family functionalities play a role in shaping children's behavior. Family functionalities are reflected in interactions that occur in a family. The emergence of social problems of children in society due to poor relations between family members. ${ }^{50}$

The family as the first institution in human resource development is based on the Bronfenbrenner learning environment theory, known as "The Learning Environment". The framework describes four environmental systems that are visualized as nest structures, in which the inside is part of an outer structure. The four systems are: 1) the microsystem, especially the "dyadic" relationship between children and primary caregivers, 2) the mesosystem is an extension of the learning dimension in more than one setting, through the support of broader participation and interaction such as peer groups, 3) is learning from the environment in which a child does not participate directly, and 4) the macro system is the highest system, is a blueprint for the framework of the relationship between the three systems in it. From this theory can be seen that, as Burns (1979) argues, the family is the backbone of children's socialization. ${ }^{51}$

Domestic violence occupies the largest portion in cases of violence affecting children in the age range 3-6 years. $80 \%$ of the violence that befell children is carried out by their families. $10 \%$ occur in educational settings, and the rest is carried out by unknown people. There are still many Indonesian children who have not obtained guarantees for their rights, because there are still many who are victims of violence, neglect,

50 Thohir Yuli Kusmanto, "Mereka yang Tercerabut dari Masa Depannya : Analisis Sosiologis Problem Sosial Anak di Indonesia,” Sawwa: Jurnal Studi Gender 8, no. April (2013): 225.

${ }^{51}$ Thahir Yudi Kusmanto, "Mereka yang Tercerabut..., 240. 
exploitation, mistreatment, discrimination, and inhumane treatment. These actions can be categorized as child abuse or cruel treatment for children.

Child abuse includes the behavior of parental neglect of children to rape and murder behavior. Terry E. Lawson, a child psychiatrist, classifies child abuse into four types, first, emotional abuse, namely the behavior of parents ignoring children, even though parents know their children are asking for attention, for example, parents let children get wet or hungry because parents are busy and do not want to disturb, also the behavior of parents ignores the needs of children to be hugged, protected and cared for. Children will remember all emotional abuse if the emotional violence is consistent.

Verbal abuse is parents' harsh words to a child when the child asks for attention or is crying. Even when the child starts talking, parents continue to use verbal violence such as saying, "you are stupid", "you are fussy", "you are insolent", and so on. Third, physical abuse, namely parents who commit physical violence against children with any tools, when children actually need attention, such as hitting a child with their hands or wood, skin or metal will be remembered by the child. Fourth, sexual abuse usually does not occur during the first eighteen months of a child's life although there are some cases when girls suffer sexual violence at the age of six months.

Muslim families with extreme (extreme) connected-disengaged types carry out emotional and verbal abuse against children aged 3 years. Rigidly-separated mid-range family types do emotional abuse, verbal abuse, and physical abuse rarely and often. Rigidly-connected types rarely perform emotional abuse and verbal abuse. Chaotically-separated types do verbal and physical abuse frequently and rarely. Chaotically-connected types do physical abuse frequently. Flexibly-enmeshed family types rarely 
do verbal abuse. Thus the type of middle range family that performs emotional abuse often as much as $3.2 \%$, does emotional abuse rarely as much as $3.2 \%$, rarely verbal abuse $9.6 \%$, often verbal abuse $3.2 \%$, doing rarely physical abuse $6.4 \%$ and frequent physical abuse $6.4 \%$.

Balanced family types rarely do emotional abuse $30.5 \%$, often emotional abuse $7.6 \%$, frequent verbal abuse $13.9 \%$, and rarely verbal abuse $36.4 \%$. The physical abuse is never done by parents against children in balanced families. The majority of Muslim families with this type rarely do emotional abuse and verbal abuse with little frequency (rare). There is still the mid-range type of Muslim family that does physical abuse. Even though it is rarely, this type of balanced family has never done it.

Thus the virtues and features of balanced family types and their role are able to reduce violent behavior against children. A balanced type of Muslim family, the dimensions of closeness, and communication play great significant role in reducing parents' violent behavior against children. Although the balanced family type is considered ideal in the perspective of Circumplex model, it still remains emotional and verbal abuse to children with very rare frequencies.

Parents must know and understand that child neglect behavior both emotionally and verbally is included as child abuse. If it is constantly done, it will have a negative impact on the mental and intellectual development of children which in turn will shape delinquency behavior in adolescence. ${ }^{52}$ The experience of being neglected in childhood will be attached to the child soul. Respectively, it will shape the behavior of ignoring surrounding in adulthood in the years to come. All acts of violence against children are recorded in the subconscious and brought to adulthood, even throughout their lives. ${ }^{53}$ Therefore efforts

${ }^{52}$ Margaret C. Plantz dan James Garbarino, "Child abuse and juvenile delinquency: What are the links?," in Troubled youth, troubled families, Routledge, 2017, 27-40.

${ }^{53}$ Hannah C. Espeleta, Sarah Palasciano-Barton, dan Terri L. Messman-Moore, "The 
The Muslim Millennial family typology: the role of Muslim family circumflex... (Supaat, Salmah Fa'atin) are needed to prevent parental neglect and violence against children, including communication with children physically and psychologically, verbal and emotional interactions. ${ }^{54} \mathrm{~A}$ related strategy to communicate ethically appropriate teachings of Islam, Qur'an has taught the ethics of communicating that are either in general or in the context of education, in this case the family education. ${ }^{55}$

The principles and ethics of communicating in the verses of Qur'an are conveying the truth and honesty. The delivery is done without persuasion or partiality. Chatting with children using fair language, the contents are in accordance with the portions, not biased or contain certain subjectivity. Communicating with children must also speak the right language in accordance with its purpose, both in relation to its true content, as well as the way of disclosure that is not distorted, excessive or wordy.

Communicating with children using subtle language in accordance with the age and development of the child, polite language content and their ways is disclosed in accordance with community norms. Communication with children uses appropriate language according to the level or status of people who say and hear it, and contain rewards, not degrading children so that children feel they have a better spirit and future.

\section{Conclusion}

Based on the discussion above, this research draws conclusions as follow: first, the typology of the millennial Muslim families in Indonesia, based on Circumplex model, is classified into three types, the first is the extreme type of Muslim family for 3\%, the mid-range Muslim family type (mid-

impact of child abuse severity on adult attachment anxiety and avoidance in college women: the role of emotion dysregulation," Journal of family violence 32, no. 4 (2017): 399-407.

${ }^{54}$ Beverly L. Fortson et al., "Preventing child abuse and neglect: A technical package for policy, norm, and programmatic activities," 2016.

${ }^{55}$ M.Kadar Yusuf, Tafsir Tarbawi: Pesan-pesan al-Qur'an tentang Pendidikan, Jakarta: Amzah, 2015. 
range) for 32\%, and the balanced Muslim family type for $65 \%$.

Second, the majority of millennial Muslim families in Indonesia occupy the balanced family and middle range types. While Muslim families with extreme types are a few. The parents of the middle-range and balanced Muslim family types are very rarely carrying out child abuse behavior, namely emotional and verbal abuse.

Third, the parents of the extreme types of Muslim families do child abuse, namely emotional, verbal and physical abuse.

Third, the shift does not significantly affect parents' violent behavior against their children, although the millennial Muslim families in Indonesia have experienced a shift in family functions.

\section{Bibliography}

Al-Mursi, Al-Safsâfî Ahmad. Al-Qiyam al-Usriyyah bain al-Asâlah wa alMu'âsarah. Kairo: Dâr al-Âfâq al-'Arabiyyah, 2002.

Arifin, Siful. "Revitalisasi Keluarga Sebagai Lingkungan Pendidikan." Kariman: Jurnal Pendidikan dan Keislaman 5, no. 1 (2017): 1-22.

"Beth A.Latshaw and Stephanie I. Hale 'The domestic handoff': stay-athome fathers' time-use in female breadwinner families: Journal of Family Studies: Vol 22, No 2," n.d.

Doucet, Andrea, dan Laura Merla. "Stay-at-Home Fathering." Community, Work EF Family 10, no. 4 (November 2007): 455-73. https://doi. org/10.1080/13668800701575101.

Espeleta, Hannah C., Sarah Palasciano-Barton, dan Terri L. MessmanMoore. "The impact of child abuse severity on adult attachment anxiety and avoidance in college women: the role of emotion dysregulation." Journal of family violence 32, no. 4 (2017): 399-407.

Fadilah, Sri. "Kesetaraan Gender : Fenomena Pergeseran Peran Ekonomi Wanita Dari Tulang Rusuk Menjadi Tulang Punggung." Mitra

Gender (Jurnal Gender dan Anak) 1, no. 1 (2018): 18-26.

Faidah, Rohmatul. "Konsep Pendidikan Keluarga: Studi Analisis Atas Pandangan Muhammad Fauzil Adhim.” PhD Thesis, UIN Sunan 
Ampel Surabaya, 2013.

Fischer, Jessica, dan Veanne N. Anderson. "Gender role attitudes and characteristics of stay-at-home and employed fathers." Psychology of Men $\mathcal{E}$ Masculinity 13, no. 1 (2012): 16.

Fortson, Beverly L., Joanne Klevens, Melissa T. Merrick, Leah K. Gilbert, dan Sandra P. Alexander. "Preventing child abuse and neglect: A technical package for policy, norm, and programmatic activities," 2016.

Glaser, Ida. "Millennial Reverie: Muslims in Britain'." International Review of Missions 27, no. 107 (1938): 341-354.

Hakiki, Miftahul. "Pendidikan Keluarga: Membangun Kesehatan Mental Dan Karakter Anak Di Era Millenial.” An-Nisa' 10, no. 1 (2017): 115-28. http://ejournal.iain-jember.ac.id/index.php/annisa/ article/view/645/526.

Hawari, Dadang. Al-Qur'an ilmu Kedokteran jiwa dan Kesehatan Jiwa. Yogyakarta: PT Dana Bhakti Yasa, 1995.

"IPI Search Articles," n.d.

Kholis, Muhammad Nur. "Konsep Kepala Keluarga Antara Laki-Laki Dan Perempuan Dalam Surat an Nisa (4) Ayat 34.” ISTINBATH: Jurnal Hukum 12, no. 2 (2015): 274-290.

Kusmanto, Thohir Yuli. "Mereka yang Tercerabut dari Masa Depannya : Analisis Sosiologis Problem Sosial Anak di Indonesia." Sawwa: Jurnal Studi Gender 8, no. April (2013): 225-44.

Muassomah, Muassomah. "Domestikasi Peran Suami Dalam Keluarga." EGALITA, 2012.

Mulia, Siti Musdah. Membangun Surga di Bumi: Kiat-kiat Membina Keluarga Ideal dalam Islam. Jakarta: Elex Media Komputindo, 2011.

Mulyadi, Seto, Heru Basuki, dan Wahyu Rahardjo. Psikologi Pendidikan: Dengan Pendekatan Teori-teori Baru dalam Psikologi. Jakarta: Rajawali Press, 2017.

Mustaqim, Abdul. Tafsir Feminis versusTafsir Patriarkhi. Yogyakarta: Sabda Persada, 2003.

Nye, F. Ivan. Role Structure and Analysis of the Family. London: Sage Publications, 1976. 
Olson, Russel, dan Sprenkel. Circumplex Model: Systemic Assesment and Treatment of Families. New York: Haworth Press Inc, 1988.

Plantz, Margaret C., dan James Garbarino. "Child abuse and juvenile delinquency: What are the links?" In Troubled youth, troubled families, 27-40. Routledge, 2017.

Pramanada, Nazhra Aulia, dan Adi Dinardinata. "Pengalaman Suami Menjadi Stay-at-Home Dad Pada Usia Dewasa Awal (sebuah Studi Kualitatif Fenomenologis Dengan Interpretative Phenomenological Analysis)." PhD Thesis, Undip, 2018.

Rahman, Fauzeya Zahera. "Digitally defined: how Muslim millennials represent themselves online," 2015.

Rahmawati, Anita. "Harmoni dalam Keluarga Perempuan Karir: Upaya Mewujudkan Kesetaraan dan Keadilan Gender dalam Keluarga.” PALASTREN Jurnal Studi Gender 8, no. 1 (2016): 1-34.

Rusydi, Muhammad. "Relasi Laki-laki dan Perempuan dalam al-Qur'an Menurut Amina Wadud.” MIQOT: Jurnal Ilmu-ilmu Keislaman 38, no. 2 (2014).

Shihab, MQ. "Membumikan Al-Quran.” Bandung: Mizan, 1992. http:// www.academia.edu/download/35715012/membumikan-al-quran.pdf. Shihab, Quraish. Perempuan. Jakarta: Lentera Hati, 2006.

Stevens, Emily. "Understanding Discursive Barriers to Involved Fatherhood: the Case of Australian Stay-at-Home Fathers." Journal of Family Studies 21, no. 1 (Januari 2015): 22-37. https://doi.org/10 $.1080 / 13229400.2015 .1020989$.

Suharto, Toto. "Membina Keluarga Muslim Di Era Global: Pergumulan Antara Tradisi Dan Modernitas.” Musãwa Jurnal Studi Gender dan Islam 10, no. 2 (2011): 205-214.

Sutomo, Imam. "Modification of character education into akhlaq education for the global community life." IJIMS, Indonesian Journal of Islam and Muslim Societies 4, no. 2 (2014): 291-316.

Utami, Nurul. "Pengalaman Komunikasi Keluarga Istri yang Berpendapatan Lebih Besar dari Suami." Jurnal Kajian Komunikasi 4, no. 1 (2016): 95-108.

Wadud, Amina. Inside The Gender Jihad. Oxford: Oneword, 2006.

Wals, F. Normal Family Process. New York: The Guildford Press, 2003. 
The Muslim Millennial family typology: the role of Muslim family circumflex... (Supaat, Salmah Fa'atin)

Widhiastuti, Cindy \& Maria Dwi Yanika Hesti Nugraha. "Peranan Stay at Home Dad dalam Membentuk Keluarga Sehat dan Harmonis." PSIBERNETIKA 6, no. 2 (2013): 59-73.

Zakarison, Ledaman Bliss. "' Muslim, period. American, period': millennial Muslim identities in the contemporary United States," 2016.

Zuhrah, Fatimah. "Relasi Suami Dan Istri Dalam Keluarga Muslim Menurut Konsep Al-Quran: Analisis Tafsir Maudhuiy.” Analytica Islamica Journal 2, no. 1 (2013): 177-192. 
